\title{
Influence of Age on Haematological Parameters in Post-Partum Pure Bred Arabian Mares Raised in Tiaret Algeria
}

\author{
Samia Meliani*, Bouabdellah Benallou, Asmaa Hamdi and Sarra Bouabdelli
}

Veterinary Institute, University of Tiaret, Algeria

\begin{abstract}
Normal haematological values need to be defined for each breed in order to increase diagnostic precision. No published data on haematology exists for Arabian horses raised in Algeria. Hematological examination, in horses, has been performed for a variety of reasons: as a screening procedure to examine general health of the animal, as an adjunct to a patient's infection and to evaluate the progress of certain disease conditions. This research compares the haematological characteristics of post-partum pure bred Arabian mares of different ages. Twenty pure bred Arabian mares were used in this study. Four age groups with five mares each one: A (5-10 years), B (10-15), C (15-20) and $D$ (>20 years). Jugular blood samples were taken and data were pooled for each animal. In this study, the number of Red Blood Cells (RBC), hemoglobin concentration ( $\mathrm{Hb}$ ), Packed Cell Volume (PCV), average volume of red blood cells in the blood (MCV), and total number of leukocytes (WBC), Mean Corpuscular Haemoglobin (MCH) Mean Corpuscular Hemoglobin Concentration (MCHC), and platelets number were determined. In this study, a significant difference was observed between the post-partum mares with different groups of age in total erythrocyte counts, Haemoglobin and Packed cell volume $\mathrm{P}<0.05$.
\end{abstract}

Keywords: Horse; Reproduction; Arabian mares; Haematology; Horses; Blood

\section{Introduction}

Haematological analysis in horses is an important aid for clinical diagnosis of systemic, infectious and some parasitic diseases. It can also provide significant information about the response to treatment, the severity and the systemic effects of a disease, and the metabolic state of a single animal or herd [1-3]. Despite the extended use of haematology in equine medicine, interpretation may be a challenge in some cases, because it can be significantly influenced by a great number of factors. Haematological parameters may vary according to breed, sex, age, reproductive status, fitness and training levels, exercise, feeding, circadian variations, handling procedure of the animals during blood withdrawal, degree of excitement and health state [3-6].

The horse is unique in comparison to most other mammalian species in that the spleen is a very capacious organ, storing up to one third of the red blood cells, and this reserve can be mobilized by exercise, stress or excitement $[2,5,7,8]$. The degree of excitement during blood withdrawal depends on the temperament and the breed [9].

Arabian breed horses are considered hot-blooded [10]. These animals are characterized by their higher metabolic requirements, and consequently have higher levels of Red Blood Cells counts (RBC), Packed Cell Volume (PCV) and Haemoglobin ( $\mathrm{Hb}$ ), compared to horses of the other breeds, according to findings reported by $[2,3,11]$. Physiologically, higher RBC, Packed cell volume and haemoglobin levels can play a role in better physical condition, such as in sports activities [12]

The influence of age on the haematological parameters has been evaluated in different equine breeds [13-16]. In this way, the importance of appropriate ranges of reference for accurate interpretation of clinico-pathological data is well recognized in equine medicine. Most of the studies concerning the haematological parameters focused on foals from birth to four years of age $[4,17,18]$, although recently old horses have received more attention, probably because the increase in the population of geriatric animals [14,19]. It is acknowledged that for comparisons between individuals and with reference data in a clinical diagnostic situation, it is necessary to consider normal variations due to age, sex and breed, in order to increase diagnostic precision. Likewise, although the normal range of haematological parameters for the equine species falls into a broad range, the physiological variations for a determined breed are usually quite narrow $[5,8]$. As far as we are aware there are no reports concerning haematological parameters in Pure bred Arabian mares. For that reason, in the present paper, we present the haematological characteristics of Arabian mares of different ages of the pure bred Arabian mares strain used for reproductive and epic sports. The aim of this study was to verify the hypothesis that the reproductive status induces some haematological modifications in pure bred Arabian mares raised in Tiaret Algeria.

\section{Material and Methods}

The present study was conducted on twenty pure bred mares during 2012-2013 in Tiaret, Algeria. All animals belong to the national Haras of Chawchawa. The history of these animals since birth was recorded. The animals were fed barley, fodder and seasonal water ad libitum. All the mares were subjected to a general clinical examination before the taking of blood samples and in all cases, no significant clinical findings were observed. Only mares without evidence of trauma or illness before or during the study were included.

The reproductive statute of each mare was determined according to its recorded history, in conjunction with results obtained with rectal

*Corresponding author: Samia Meliani, Doctorate in Reproduction Sciences Veterinary Institute, University of Tiaret, 14000, Algeria, Tel: +213553419812; E-mail: melianisamia@hotmail.com

Received November 16, 2014; Accepted December 01, 2014; Published December 08, 2014

Citation: Meliani S, Benallou B, Hamdi A, Bouabdelli S (2014) Influence of Age on Haematological Parameters in Post-Partum Pure Bred Arabian Mares Raised in Tiaret Algeria. J Microb Biochem Technol 7: 008-010. doi:10.4172/1948 5948.1000174

Copyright: @ 2014 Monteiro VN, et al. This is an open-access article distributed under the terms of the Creative Commons Attribution License, which permits unrestricted use, distribution, and reproduction in any medium, provided the original author and source are credited 


\begin{tabular}{|c|c|c|c|c|c|}
\hline \multirow{2}{*}{ Group of age } & $A(n=5)$ & $B(n=5)$ & $C(n=5)$ & $D(n=5)$ & \multirow{3}{*}{$\mathbf{p}$} \\
\hline & $5-10$ years & $10-15$ years & $15-20$ years & $>20$ years & \\
\hline Parameters & Mean \pm SD & Mean \pm SD & Mean \pm SD & Mean \pm SD & \\
\hline Total leukocyte counts (U/ml) & $10040,00 \pm 1054,32$ & $8020,00 \pm 352,70$ & $9080,00 \pm 946,26$ & $10120,00 \pm 727,60$ & 0,34 \\
\hline Total erythrocyte counts (X 10 $12 / L)$ & $8,68 \pm 0,43$ & $6,92 \pm 0,23$ & $7,32 \pm 0,68$ & $6,48 \pm 0,37$ & 0,03 \\
\hline Haemoglobin (g/dL) & $14,86 \pm 1,00$ & $13,20 \pm 0,35$ & $12,14 \pm 0,60$ & $12,44 \pm 0,64$ & 0,04 \\
\hline Packed cell volume (\%) & $38,08 \pm 1,12$ & $37,18 \pm 0,54$ & $36,52 \pm 1,97$ & $34,16 \pm 1,36$ & 0,02 \\
\hline $\operatorname{MCV}(\mathrm{fl})$ & $46,00 \pm 0,71$ & $51,66 \pm 1,74$ & $53,40 \pm 2,73$ & $54,40 \pm 3,74$ & 0,19 \\
\hline TCMH (pg) & $16,98 \pm 0,31$ & $17,92 \pm 0,38$ & $18,22 \pm 1,44$ & $17,52 \pm 2,63$ & 0,74 \\
\hline $\mathrm{MCHC}(\mathrm{g} / \mathrm{dl})$ & $37,14 \pm 0,44$ & $35,52 \pm 1,00$ & $34,38 \pm 1,31$ & $35,44 \pm 1,22$ & 0,24 \\
\hline Platelet (U/ml) & $194600,00 \pm 25,75$ & $173600,00 \pm 17,00$ & $208200,00 \pm 29,41$ & $194800,00 \pm 45,03$ & 0,46 \\
\hline
\end{tabular}

Table $N^{\circ} 01$ : Mean \pm SD values for blood samples of post partum mares.

examination and the ultrasonography. The first samples were taken from pregnant mares in the last trimester of pregnancy; the second were performed in the week after parturition and the third one month later. So that mares were assigned to three categories: pregnant, postpartum and lactating mares.

Jugular blood samples were collected, directly in sterile heparinized test tubes, from each mare early in the morning before feeding. The blood samples were brought to the biochemical laboratory within two hours for analysis. In the whole blood samples the number of Red Blood Cells (RBC), hemoglobin concentration ( $\mathrm{Hb})$, Packed Cell Volume $(\mathrm{PCV})$, average volume of red blood cells in the blood (MCV), and total number of leukocytes (WBC), Mean Corpuscular Haemoglobin $(\mathrm{MCH})$, Mean Corpuscular Hemoglobin Concentration (MCHC), and platelets number were determined using an automatic cell counter. For each category, mean and standard deviation values were determined. Data of various categories were analyzed statistically using by ANOVA and the significance level of $\mathrm{P}<0.05$.

\section{Results and Discussion}

This research assesses the haematological differences when comparing post-partum Pure bred Arabian mares of different ages. The results of different data are given in Table 1. Haematology has been widely used to provide information about disease status, performance problems, and fitness in horses. Age, sex and breed as well as physical exercise may affect the results of haematologic values [20,21]. In the present study, in general all haematological parameters were consistent with previous reports [22-24].

In this study, a significant difference was observed between the post-partum mares with different groups of age in total erythrocyte counts, Haemoglobin and Packed cell volume $\mathrm{P}<0.05$. In the advanced stage of gestation, there is an endogenous adrenaline release which induces the greater mobilization of neutrophils in the circulation resulting in an increase in total leucocyte count [6]. During the last period of gestation the number of leucocytes increased gradually being higher [12]. The reduction in total erythrocyte counts with ageing has been described already in Standard-bred trotters [13,17,25], Lipizzaner [26], Spanish Purebred [16] and feral horses [27]. The Group D of postpartum mares presented significantly lower total erythrocyte counts values than Group A of the same category. This fact could have been related to a reduced regenerative capacity of the bone marrow, the presence of subclinical chronic diseases and/or pituitary-dependent hyperadrenocorticism (pars intermedia dysfunction). The main reason for the lower total erythrocyte counts in older broodmares was considered to be the degree of activity of the bone marrow [28]. Increased erythrocyte size seems to be a frequent finding associated with ageing in horses $[13,14,16]$.
Normal values of haemoglobin and erythrocytes of young animals are lower than adults [29] (Table 1). With aging, the total count of leukocytes shows a lowering trend, while the percent of neutrophils rises. However, [30] reported that erythrocytes, lymphocytes and fibrinogen decreased with age. Sex and lactation had no effect on haemato-biochemical parameters in healthy animals $[18,29,30]$.

In this study no significant difference was observed when the different parameters were compared according to the reproductive status. Factor such as breed and physiological changes during the pregnancy did not influence the results in this study in difference with [31]. Nevertheless, factor such age generates differences in the studied variables agreeing with [12]. Packed cell volume and haemoglobin diminished during the final period of pregnancy. According to [32], fetal growth that occurs in that period of pregnancy produces a greater oxygen demand. This greater need for oxygen is compensated by the endocrine system that stimulates the release of erythropoietin by the renal tissue [33]. The secretion of this circulating glycoprotein stimulates increased production of erythrocytes in the bone marrow [34]. This phenomenon, which has been described in pregnant rabbits [35] and pregnant women [32], has also been observed in Arabian pregnant mares [12]. There is $40-50 \%$ an increase in blood's volume for pregnant women [32]. This means an increase in plasma volume as well the total number of erythrocytes and leukocytes in the blood circulation, which are produced by physiological adjustments in the endocrine and renal systems.

The reduction in RBC, Packed cell volume and haemoglobin, occurs in the third period of gestation, which represents the main cause of "pregnant physiological anemia" a clinical condition described in various species $[32,35]$.

Another possible physiological cause of the decline in $\mathrm{Hb}$ is the reduced average lifespan of circulating erythrocytes in pregnant females compared to non-pregnant ones [34]. According to the author, this condition leads to a hematopoietic emergency, promoting an increase in erythropoietin concentration and erythrocytes. The results found for MCV and RBC suggest an increase in the number of immature erythrocytes, which would be in accordance with findings in pregnant rats, rabbits and women reported by $[34,35]$. The $\mathrm{MCH}$ increased in the two breeds during the third pregnant period. These findings were attributed to the possible presence of immature erythrocytes in the peripheral blood [11].

The values found for lymphocytes were the normal range of horses [11,31]. However these numbers were closer to those obtained in Arabian pregnant mares [12] which were higher to those found in Thoroughbreds [36].

In this study some haematological parameters was influenced by 
Citation: Meliani S, Benallou B, Hamdi A, Bouabdelli S (2014) Influence of Age on Haematological Parameters in Post-Partum Pure Bred Arabian Mares Raised in Tiaret Algeria. J Microb Biochem Technol 7: 008-010. doi:10.4172/1948-5948.1000174

the age of the mare and by the reproductive status. The results of this investigation show that the variations associated with age in horses occur regardless of the physiological state of the mare.

\section{References}

1. Ricketts SW (1987) The laboratory as an aid to clinical diagnosis. Vet Clin North Am Equine Pract 3: 445-460.

2. Lassen ED, Swardson CJ (1995) Hematology and hemostasis in the horse: normal functions and common abnormalities. Vet Clin North Am Equine Pract 11: 351-389.

3. Messer NT IV (1995) The use of laboratory tests in equine practice. Vet Clin North Am Equine Pract 11: 345-350.

4. Jain NC (1993) Comparative hematology of common domestic animals. In: Jain, NC (ed.): Essentials of Veterinary Hematology. 1st ed. Lea and Febiger, Philadelphia, pp. 19-53.

5. Rose RJ, Hodgson DR (1994) Hematology and biochemistry. In: Hodgson DR, Rose RJ (eds.): The athletic horse: principles and practice of equine sports medicine. WB Saunders, Philadelphia, pp. 63-76. 6.

6. Kramer JW (2000) Normal hematology of the horse. In: Feldman BF, Zinkl JG, Jain NE (eds.): Schalm's Veterinary Hematology. Lippincott Williams and Wilkins, Philadelphia, pp. 1069-1074

7. Persson S (1967) On blood volume and working capacity in horses. Studies of methodology and physiological and pathological variations. Acta Vet Scand .

8. Schalm OW, Jain NC, Caroll EJ (1975) Veterinary Haematology. 3rd ed. Lea and Febiger, Philadelphia, pp. 15-81.

9. Rubio MD, Muñoz A, Santisteban R, Tovar P, Castejón FM (1995) Comparative hematological study of two breeds of foals (Andalusian and Arab) subjected to exercise of progressive intensity. J Vet Med Sci 57: 311-315.

10. Kaneko JJ (1997) Serum proteins and the dysproteinemas. In: Kaneko J, Harvey JW, Bruss ML (eds.): Clinical Biochemistry of Domestic Animals. 5th ed. Academic Press, San Diego, pp. 117-137.

11. Morris DD (1998) Enfermedades del sistema hemolinfático. In: Colahan, PT, Mayhew, IG Medicina y cirugia equina. 4.ed. Buenos Aires: Inter-Médica 2: 1619- 1678.

12. Vaz BBD, Lacerda Neto JC de, Santana ÁE, Summa RP, Penteado C (2000) Constituintes hematimétricos do sangue de éguas gestantes da raça Árabe. Veterinária Noticias 6: 51-55.

13. Ralston SL, Nockels CF, Squires EL (1988) Differences in diagnostic test results and hematologic data between aged and young horses. Am J Vet Res 49: 1387-1392

14. McFarlane D, Sellon DC, Gaffney D, Hedgpeth V, Papich M, et al. (1998) Hematologic and serum biochemical variables and plasma corticotropin concentration in healthy aged horses. Am J Vet Res 59: 1247-1251.

15. Cebulj-Kadunc N, Kosec M, Cestniki V (2003) The variations of white blood cell count in Lipizzan horses. J Vet Med A Physiol Pathol Clin Med 50: 251-253.

16. Satue K, Hernandez A, Lorente C (2008) Erythrocyte parameters in Spanish horse: influence of age and gender. Proceedings of 10 th Annual Congress of the European Society of Veterinary Clinical Pathology (ESVCP) and the 8th Biennial Congress of the International Society for Animal Clinical Pathology (ISACP), European Society of Veterinary Clinical Pathology, CAB Abstracts, Barcelona, Spain 163-164.

17. Stewart GA, Clarkson GT, Steel JD (1970) Hematology of the racehorse and factors affecting interpretation of the blood count. Proceedings of the Annual Convention of the American Association of Equine Practitioners 16: 17-35.

18. Harvey RB, Hambright MB, Rowe LD (1984) Clinical biochemical and hematologic values of the American Miniature Horse: reference values. Am J Vet Res 45: 987-990.
19. Paradis MR (2002) Demographics of health and disease in the geriatric horse Vet Clin North Am Equine Pract 18: 391-401.

20. Karazawa EH, Jamra M (1989) Normal hematologic parameters. Rev Saude Publica 23: 58-66.

21. Kaneko J, Harvey JW, Bruss ML (1997) Clinical Biochemistry of Domestic Animals. 5th Ed., Academic Press, San Diego, USA pp 485-516.

22. Duncan JR, Prasse KW, Mahaffey EA (1994) Veterinary Laboratory Medicine: Clinical Pathology. 3rd Ed., lowa State Univ. Press, Ames, lowa, USA.

23. Eades SC, Bounous DI (1997) Laboratory Profile of Equine Diseases. Mosby Year Book. Saint Louis, Missouri, USA.

24. Meyer DJ, Harvey JW (1998) Veterinary Laboratory Medicine: Interpretation and Diagnosis. 2nd Ed., Saunders, Philadelphia, USA.

25. Jain NC (1986) The horse. Normal haematologic with comments on response to disease. In: Jain NC (ed.): Schalm's Veterinary Hematology. 4th ed. Lea \& Febiger, Philadelphia, pp. 140-177.

26. Cebulj-Kadunc N, Bozic M, Kosec M, Cestnik V (2002) The influence of age and gender on haematological parameters in Lipizzan horses. J Vet Med A Physiol Pathol Clin Med 49: 217-221.

27. Plotka ED, Eagle TC, Gaulke SJ, Tester JR, Siniff DB (1988) Hematologic and blood chemical characteristics of feral horses from three management areas. $J$ Wild Dis 24: 231-239.

28. Satue K, Blanco O, Munoz A (2009) Age-related differences in the hematological profile of Andalusian broodmares of Carthusian strain. Veterinarni Medicin 54 175-182.

29. Dinev D, Khubenov KhD (1986) Normal values of the hematological, biochemica and enzymological indices of the donkey. Vet Med Nauki 23: 69-75.

30. Zinkl JG, Mae D, Guzman Merida P, Farver TB, Humble JA (1990) Reference ranges and the influence of age and sex on hematologic and serum biochemical values in donkeys (Equus asinus). Am J Vet Res 51: 408-413.

31. Taylor-MacAllister C, MacAllister CG, Walker D, Aalseth D (1997) Haematology and serum biochemistry evaluation in normal postpartum mares. Equine Vet $J$ 29: 234-235.

32. Souza AI, Filho MB, Ferreira LOC (2002) Alterações hematológicas e gravidez. Revista Brasileira de Hematologia e Hemoterapia 24: 29- 36.

33. Plaschka S, García López P, Rivera L, Martín Fernández J, Lema L, et al (1997) Parámetros hematológicos y bioquímicos en el parto de la yegua de raza española. Medicina Veterinaria 14: 205-209.

34. Lurie S (1993) Changes in age distribution of erythrocytes during pregnancy: a longitudinal study. Gynecol Obstet Invest 36: 141-144.

35. Kim JC, Yun HI, Cha SW, Kim KH, Koh WS, et al. (2002) Haematologica changes during normal pregnancy in New Zealand white rabbits: a longitudinal study. Comparative Clinical Pathology 11: 98-106.

36. Feldman BF (2000) Schalm's veterinary hematology. Philadelphia: Williams and Wilkins pp. 1344. 